\title{
Patient-Derived Induced Pluripotent Stem Cells and Organoids for Modeling Alpha Synuclein Propagation in Parkinson's Disease
}

\author{
Yong Hui Koh ${ }^{1,2}$, Li Yi $\operatorname{Tan}^{1}$ and Shi-Yan $\mathrm{Ng}^{1,2,3,4 *}$ \\ 1 Institute of Molecular and Cell Biology, Singapore, Singapore, ${ }^{2}$ Department of Physiology, Yong Loo Lin School of Medicine, \\ National University of Singapore, Singapore, Singapore, ${ }^{3}$ National Neuroscience Institute, Singapore, Singapore, ${ }^{4}$ The Third \\ Affliated Hospital of Guangzhou Medical University, Guangzhou, China
}

Parkinson's disease (PD) is an age-associated, progressive neurodegenerative disorder characterized by motor impairment and in some cases cognitive decline. Central to the disease pathogenesis of PD is a small, presynaptic neuronal protein known as alpha synuclein (a-syn), which tends to accumulate and aggregate in PD brains as Lewy bodies or Lewy neurites. Numerous in vitro and in vivo studies confirm that a-syn aggregates can be propagated from diseased to healthy cells, and it has been suggested that preventing the spread of pathogenic a-syn species can slow PD progression. In this review, we summarize the works of recent literature elucidating mechanisms of a-syn propagation, and discussed the advantages in using patient-derived induced pluripotent stem cells (iPSCs) and/or induced neurons to study a-syn transmission.

OPEN ACCESS

Edited by:

Alessandro Tozzi,

University of Perugia, Italy

Reviewed by:

Daniela Merlo,

Istituto Superiore di Sanità (ISS), Italy

Daniella Rylander Ottosson,

Lund University, Sweden

*Correspondence:

Shi-Yan Ng

syng@imcb.a-star.edu.sg

Received: 11 June 2018

Accepted: 23 October 2018

Published: 09 November 2018

Citation:

Koh YH, Tan LY and Ng S-Y (2018) Patient-Derived Induced Pluripotent

Stem Cells and Organoids for Modeling Alpha Synuclein

Propagation in Parkinson's Disease.

Front. Cell. Neurosci. 12:413.

doi: 10.3389/fncel.2018.00413
Keywords: iPSCs, alpha synuclein ( $\alpha$-synuclein), lewy body disease, organoids, disease modeling

\section{INTRODUCTION}

Parkinson's disease (PD) is a progressive and chronic neurological disorder and the second most prevalent neurodegenerative disease after Alzheimer's disease, affecting an estimated seven to ten million people worldwide. Dopaminergic (DA) neurons in the substantia nigra par compacta $(\mathrm{SNpc})$ are selectively lost in $\mathrm{PD}$, leading to a constellation of motor deficits that include bradykinesia (slowed movements), tremors and muscle rigidity. In some patients, symptoms of dementia are also present. Approximately 15\% of people with PD have a family history of the disease (termed familial PD) while the others are sporadic cases. Mutations in several genes are each associated with the occurrence of $\mathrm{PD}$, including alpha synuclein (SNCA), leucine-rich repeat kinase 2 (LRRK2), and other autosomal recessive mutations in genes such as Parkin (PARK2), PTEN-induced putative kinase 1 (PINK1) and Protein/nucleic acid deglycase DJ-1 (PARK7), and has been extensively reviewed in Klein and Westenberger (2012). Although the exact cause for sporadic PD is yet to be identified, the largest risk factors for PD are genetics, advanced age and exposure to environmental toxins such as paraquat (Ascherio and Schwarzschild, 2016).

One of the pathological hallmarks of PD is the formation of intracellular inclusions termed Lewy bodies, which are caused by aggregates of a-syn protein. Multiple in vivo studies-both human and mouse-have confirmed that a-syn aggregates can be transferred from affected neurons to healthy neural cells (Kordower et al., 2008; Li et al., 2008; Pan-Montojo et al., 2012; Recasens et al., 2014). It is becoming increasingly appreciated that misfolded a-syn can transmit to anatomically connected areas (Braak et al., 2003), and this could explain why a substantial proportion of PD 
patients also suffer from cognitive impairment, depression and psychosis. Several mechanisms of a-syn transmission have been proposed, including receptor-mediated endocytosis, direct cellto-cell transfer through tunneling nanotubes or through a transsynaptic pathway (Pan-Montojo et al., 2010; Luk et al., 2012b; Holmes et al., 2013; Abounit et al., 2016; Mao et al., 2016; Rostami et al., 2017). Although the mechanism of spread remains slightly controversial, it is well accepted that limiting the spread of a-syn aggregates can slow the progression of $\mathrm{PD}$, and potentially prevent other PD-associated decline in cognitive functions.

In recent years, scientific advances in the field of induced pluripotent stem cells (iPSCs), direct reprogramming into induced neurons and the formation of neural organoids have enabled the modeling of PD using patient-derived cells, and opened up possibilities for the discovery of prognostic and therapeutic agents. Over the years, differentiation protocols have dramatically evolved to give rise to specific midbrain DA neuron populations that are lost in PD. From co-culture with mouse PA6 or MS5 stromal cells (Kawasaki et al., 2000; Perrier et al., 2004) that gave rise to low DA neuron yield, midbrain DA differentiation has now become more reproducible and efficient with chemically defined protocols (Kriks et al., 2011; Kirkeby et al., 2012; Doi et al., 2014; Paik et al., 2018). Disease modeling efforts by multiple groups worldwide has now uncovered that midbrain DA neurons derived from PD patients exhibit mitochondrial dysfunction and a-syn aggregation (Devi et al., 2008; Byers et al., 2011; Cooper et al., 2012; Imaizumi et al., 2012; Ryan et al., 2013; Flierl et al., 2014; Shaltouki et al., 2015; Chung et al., 2016; Kouroupi et al., 2017). iPSCderived midbrain DA neurons are also useful for potential cell replacement therapies, an undertaking that is initiated by the GForce-PD group, a global team of scientists and clinicians that are committed to accelerate the translation of stem cellbased therapies to the clinic for Parkinson's disease human trials (Barker et al., 2015). While cell replacement therapy can correct the motor deficits in PD patients, it is unlikely to rectify the non-motor symptoms such as dementia, depression, delusions or hallucinations, which are common in advanced-staged PD patients. Therefore, slowing down PD progression remains an attractive therapeutic option. The focus of this mini-review will be to highlight the complexity of a-syn propagation and how iPSC-derived cell types and organoids can address some of this complexity.

\section{ALPHA SYNUCLEIN PROPAGATION AS THE CENTRAL MECHANISM IN THE DEVELOPMENT OF PD}

Lewy bodies and lewy neurites are the histological hallmark of PD. The main protein constituent of Lewy bodies and Lewy neurites is a-syn, a 140-amino acid presynaptic nerve terminal protein that comprises an amphipathic N-terminal alpha-helical domain, a hydrophobic center of non-amyloid beta component and a hydrophilic C-terminal domain. Under the native physiological state, a-syn does not have a defined structure and exists in an amorphic state. Although the exact functions of a-syn is still unknown, knockout studies have revealed roles of a-syn in synaptic vesicle release and trafficking, fatty acid binding, and the regulation of enzymes and transporters that are essential for neuronal survival (Sharon et al., 2001; Kanaan and Manfredsson, 2012; Stefanis, 2012). In the pathological state, a-syn becomes misfolded and therefore prone to aggregation. First, it forms soluble oligomers and then further aggregate into insoluble fibrils. These insoluble fibrils are made up of $\beta$-sheets consisting of two or more polypeptide chains connected by hydrogen bonds. Although the exact pathogenic form of a-syn is still debatable, recent studies suggest that soluble oligomers could be more toxic than insoluble fibrils (Karpinar et al., 2009; Winner et al., 2011); presumably because soluble oligomers can be transmitted more readily than insoluble fibrils. The misfolding, aggregation and accumulation of a-syn has serious neurotoxic implications (Stefanis et al., 2001; Tanaka et al., 2001; Snyder et al., 2003; Cuervo et al., 2004; Xilouri et al., 2009; Kamp et al., 2010; Nakamura et al., 2011), and is extensively reviewed in Lashuel et al. (2012). A-syn is also thought to be the pathogenic agent that underlies the progression of $\mathrm{PD}$ when toxic a-syn species transmit from diseased to healthy cells.

Braak and colleagues first suggested a prion-like mechanism in PD progression (Braak et al., 2003). They proposed that Lewy pathology spread through a stereotyped pattern of six stages, beginning from the peripheral nervous system of the gut and olfactory bulb and gradually progresses into the central nervous system. Within the brain, it spreads from the brainstem to the multiple cortical regions of the brain in a caudal-to-rostral fashion. Following on, in 2008, the serendipitous discoveries from two separate studies uncovered the presence of Lewy bodies in grafted neurons of PD patients whom have received transplantation a decade or two ago (Kordower et al., 2008; Li et al., 2008). Such observation further supports the prionlike spreading of a-syn in PD. Subsequently, many groups have attempted to recapitulate the prion-like capacity of a-syn in in vivo and in vitro models. The first few studies demonstrated the host-to-graft transfer of a-syn by transplanting neural stem cells or naïve rodent neurons into the brains of transgenic mice expressing human a-syn (Desplats et al., 2009; Hansen et al., 2011; Kordower et al., 2011; Angot et al., 2012). It was shown that human a-syn was taken up by the grafted cells and can act as a seeding template or a nucleation process to form aggregates with the intracellular mouse a-syn. In a unique mouse model that incorporates both preformed fibrils (PFFs) and a-syn overexpression, it was also shown that PFFs were necessary for the transmission of a-syn as simply overexpression of a-syn was not sufficient to result in the propagation phenomenon (Thakur et al., 2017). Other studies went even further to prove the prionlike capacity of a-syn when pathogenic a-syn were detected in neurons distant from the site of injection (Luk et al., 2012a,b; Mougenot et al., 2012; Rey et al., 2013; Sacino et al., 2013; Recasens et al., 2014; Peelaerts et al., 2015; Shimozawa et al., 2017).

The molecular mechanisms of a-syn propagation are slowly becoming unraveled. Detection of extracellular a-syn confirmed that cells secrete a-syn either as a naked entity or packaged 
into exosomes and exocytosed (Emmanouilidou et al., 2010; Danzer et al., 2012). Soluble oligomeric and monomeric asyn were readily detected in cell culture media, in a calciumdependent manner (Emmanouilidou et al., 2010), suggesting that dysregulation in neuronal activity can impact a-syn exocytosis and propagation. In humans, monomeric and oligomeric a-syn are also detected in human blood plasma and cerebrospinal fluid (Borghi et al., 2000; El-Agnaf et al., 2006; Lee et al., 2006; Tokuda et al., 2006), with increased levels of oligomeric a-syn in PD patients (El-Agnaf et al., 2006). It is also shown that elevated a-syn burden, caused by increased a-syn production (through overexpression or duplication and triplication mutations), or reduced clearance through lysosomal or proteosomal systems, would increase a-syn exocytosis (Alvarez-Erviti et al., 2011; Lee et al., 2013; Fernandes et al., 2016). Extracellular a-syn can interact with different surface proteins on the cells that facilitate its uptake via receptor-mediated endocytosis. Heparan sulfate proteoglycan interact with a-syn fibrils and induce uptake via macropinocytosis (Holmes et al., 2013). By means of a proteomics screen, Mao et al. (2016) has identified a few surface proteins that interact well with preformed fibrils (PFFs) of a-syn (Mao et al., 2016). Lymphocyte-activation gene 3 (LAG3) was one receptor found to have the strongest interaction specifically to a-syn PFFs but not monomers. LAG3, a transmembrane protein, facilitates the uptake of a-syn PFFs in neighboring neurons, astrocytes and microglial via endocytosis. Through genetic knockdown and antibody-blocking intervention, uptake of a-syn was reduced, which led to decreased neuronal toxicity and inter-neuronal propagation in vitro and in vivo (Mao et al., 2016).

One major caveat of the abovementioned studies is the assumption that fibrillar forms of a-syn are present extracellularly. Indeed, a-syn has been detected in human cerebrospinal fluid (CSF) exosomal vesicles (Alvarez-Erviti et al., 2011; Danzer et al., 2012; Stuendl et al., 2016), but these are mainly soluble a-syn monomers or oligomers. It is not clear whether fibrillar forms of a-syn are present extracellularly.

\section{VARIOUS NEURAL CELL TYPES CONTRIBUTE TO ALPHA SYNUCLEIN PATHOLOGY}

Alpha synuclein deposits are also found in astrocytes at advanced disease stages (Braak et al., 2007) and in oligodendrocytes as glial cytoplasmic inclusions (Ubhi et al., 2011). This means that pathogenic a-syn can also be transferred from neurons to other cell types such as astrocytes and oligodendrocytes. Astrocytes have been observed to take up extracellular a-syn in vitro (Lee et al., 2010; Fellner et al., 2013; Rannikko et al., 2015; Lindström et al., 2017). Glial cytoplasmic inclusions develop despite the lack of a-syn mRNA in oligodendrocytes (Miller et al., 2005), suggesting that a-syn is not produced by the oligodendrocytes but rather internalized from the external microenvironment. Studies have shown that monomeric and oligomeric forms in a-syn are internalized by oligodendrocytes in vitro (Kisos et al.,
2012; Konno et al., 2012) and in vivo (Reyes et al., 2014) with suggestions of dynamin-mediated mechanisms involved in the uptake. Overall, the role of astrocytes and oligodendrocytes in pathogenic a-syn propagation or $\mathrm{PD}$ disease progression remain largely unknown. Studies by Abounit et al. (2016) proposed a model for propagation of pathogenic a-syn species by interneuronal transfer of fibrillar a-syn-laden lysosomes. a-syn PFFs within specialized cellular structures known as tunneling nanotubes (TNTs) were detected and these can seed soluble asyn aggregation in the cytosol of recipient cells (Abounit et al., 2016). Apart from interneuronal TNTs, inter-astrocytic TNTs also spread a-syn aggregates. Using human embryonic stem cell-derived astrocytes, Rostami et al. (2017) demonstrated that failure of diseased astrocytes to degrade a-syn PFFs led them to unload their burden to surrounding astrocytes through TNTs (Rostami et al., 2017).

It is postulated that astrocytes and microglia play key roles in clearance of toxic a-syn species from the extracellular environment, and consistent with this notion, astrocytes are capable of extensive uptake of a-syn oligomers, which they then attempt to degrade via the lysosomal pathway (Lindström et al., 2017). Incomplete degradation caused by a-syn overburden can result in cellular damage in recipient astrocytes, including lysosomal defects and mitochondrial damage. Internalization of a-syn has also been shown to cause astrocyte activation and neuroinflammation (Yu et al., 2018), which impacts neuronal survival. Microglia are the primary immune cells of the central nervous system, and are known to be activated by aggregated a-syn (Zhang et al., 2005). In particular, microglial phagocytosis of a-syn was thought to be a mechanism that promotes a-syn clearance. It has been reported by several studies that toll-like receptor 4 (TLR4) is required for a-syn dependent activation of microglia, and TLR4 ablation led to impaired microglia phagocytosis and suppressed cytokine release, enhancing neurodegeneration in those mice (Stefanova et al., 2011; Fellner et al., 2013).

Taken together, these are key evidence supporting the notion that propagation of a-syn is a key driver underlying PD pathogenesis and progression; and that interaction between multiple cell types regulate this process. Therefore, cellular systems using neuroblastoma cell lines (such as mouse Neuro2a and human SH-SY5Y) or neural stem cell lines do not recapitulate the complexity of a-syn propagation. Animal models are also valuable tools for studying a-syn propagation. To this end, wild-type mice with a single inoculation of a-syn fibrils or pathological a-syn purified from postportem PD brains showed a-syn propagation to anatomically connected brain regions (Luk et al., 2012b; Blesa and Przedborski, 2014; Masuda-Suzukake et al., 2014; Recasens et al., 2014) that is reviewed in Blesa and Przedborski (2014). Though important, the conservation of a-syn transmission between mouse and human has to be established, and that eventual drug screening approaches would be more feasible and have a high throughput if performed in cultured human cells. Therefore, we propose that human induced pluripotent stem cell (iPSC)-derived neurons and neural organoids are ideal cellular platforms for studying a-syn pathology. 


\section{INDUCED PLURIPOTENT STEM CELLS AND MIDBRAIN DIFFERENTIATION}

Induced pluripotent stem cells or iPSCs revolutionize the way human diseases are modeled in vitro. iPSCs are typically skin or blood cells genetically reprogrammed to revert back to an embryonic stem cell (ESC)-like state by ectopic expression of ESC transcription factors OCT4, SOX2, c-MYC and KLF4 (Takahashi and Yamanaka, 2006). Several methods of reprogramming iPSCs have now been described (Takahashi and Yamanaka, 2006; Carey et al., 2009; Sommer et al., 2009; Somers et al., 2010) and are also summarized in Table 1 and reviewed in Malik and Rao (2013) and Seki and Fukuda (2015). Importantly, these iPSCs behave like ESCs with the capacity to self-renew and retain its pluripotency. iPSCs also retain the genetic mutations from their donors, making these attractive cellular models for modeling human diseases. Thus far, human iPSCs has become a promising tool to address the ethical issues of handling embryonic material, clinical applications for personalized treatments, and research applications as model systems to investigate human diseases in the fields of neuro-developmental and degenerative diseases (Ardhanareeswaran et al., 2017).

For meaningful disease modeling, one of the greatest hurdles is to be able to produce large amounts of the cell type of interest with high efficiency and reproducibility. One of the earliest methods of deriving DA neurons from ESCs was to co-culture with stromal feeder cells MS5 or PA6 (Kawasaki et al., 2000; Perrier et al., 2004). This stromal co-culture method, however, was chemically undefined, resulting in a heterogeneous population of neurons with overall low DA neuron yield, and the physical co-culture of human iPSCs with mouse stromal cells made it undesirable for downstream analyses or applications. The labs of Lorenz Studer and Malin Parmar have made significant progress in a chemically defined protocol for efficient differentiation of midbrain DA neurons. These methods made use of the knowledge on developmental patterning to efficiently differentiate iPSCs into midbrain-regionalized floorplate progenitor cells (Fasano et al., 2010; Kirkeby and Parmar, 2012) using chemical inhibitors of SMAD signaling (achieved by LDN-193189 and SB431542), early high-dose Sonic Hedgehog ( $\mathrm{SHH}$ ) pathway agonists (such as Purmorphamine or recombinant $\mathrm{SHH}$ ) and partial glycogen synthase kinase (GSK) inhibitors/Wnt activation (by CHIR99021) (Cooper et al., 2010; Devine et al., 2011; Kriks et al., 2011; Kirkeby et al., 2012). This revised strategy produces midbrain DA neurons that expresses the specific forehead box protein A2 (FOXA2) and LIM Homeobox Transcription Factor 1 Alpha (LMX1A) markers and demonstrates efficient dopamine release in vitro (Kirkeby et al., 2012) and in vivo after transplantation (Kriks et al., 2011).

However, even with a chemically-defined approach, a heterogeneous mix of both substantia nigra pars compacta (SNpc or A9-subtype) and ventral tegmental area (VTA or A10subtype) DA neurons are produced, and it remains a challenge to derive only A9 DA neurons-the neuronal subtype that is lost in PD. Previous work from the laboratories of Ole Isacson and Thomas Perlmann showed that the transcription factor Orthodenticle Homeobox 2 (Otx2) is a marker, and controls the specification of mouse A10 VTA DA neurons, while Sox6 defines the A9 SNpc DA neurons (Panman et al., 2014). SOX6 is also shown to localize to neuromelanin and Tyrosine hydroxylase (TH)-positive neurons in the human SNpc (Panman et al., 2014). A recent article that made use of single cell RNA profiling confirmed that Sox6 and Otx2 mark SNpc and VTA neurons respectively, while also adding a panel of genes specific to SNpc vs. VTA that they found from single cell RNA-seq (Poulin et al., 2014). This genetic information would be helpful in subsequent efforts to direct A9 DA neuronspecific differentiation. One possibility is to overexpress SOX6, or knockdown OTX2 expression in iPSC-derived floorplate cells as they differentiate into neurons. It has previously been shown in mice that ablation of Otx2 results in severely diminished VTA DA neuron differentiation (Di Giovannantonio et al., 2013) but it remains to be determined if overexpression of SOX6 and/or knockdown of OTX2 will drive the SNpc DA neuron transcriptional program in human iPSC-derived cultures.

\section{BRAIN ORGANOIDS AND DISEASE MODELING}

More recently, the ability to generate three-dimensional (3D) neural organoids has challenged the way we think about conventional cellular differentiation and disease modeling approaches. The two-dimensional approach to differentiate cells forces cells into a monolayer that is uniformly exposed to extracellular signals but does not represent their in vivo context, and does not fully maintain the complex cell-cell and cellmatrix interactions, resulting in the tendency to lose important physiological function. A landmark paper by Lancaster et al. (2013) showed that neural organoids mimick the cytoarchitecture of the developing cortex. The development of a protocol for brain-like organoids focused on two aims: the induction and differentiation of neural tissue and achieving a 3-D spatial organization that captures the development of specific brain regions. Firstly, iPSCs can be stimulated to form germ layers within iPSC aggregates known as embryoid bodies (EBs) (Evans, 2011). Specific media compositions are used to induce the formation of neural rosettes (Zhang et al., 2001) (polarized organization of epithelial cells) within the EBs. The subsequent change to differentiation medium (usually Neurobasal medium and B27 supplement for neuronal survival and differentiation with specific morphogens) facilitates the development of an organized neuroepithelium that would form various brain structures. Due to the absence of a basement membrane for the EBs to establish proper apical-basal polarity to form the neuroepithelium, an external structural support is required to ensure proper orientation of the neuroepithelium. For most organoid protocols, hydrogels (usually matrigel) are used to encapsulate the EBs to promote the accurate growth and formation of brain-like structures. When EBs are encapsulated within stagnant matrigel droplets, the diffusion of nutrients and oxygen is very poor causing death to the cells at the center of the organoids. Hence, after establishing the proper growth and 
TABLE 1 | Gene delivery methods used for iPSC generation.

\begin{tabular}{|c|c|c|c|c|}
\hline Methods & Types & Subtypes & Advantages & Disadvantages \\
\hline \multirow[t]{3}{*}{ Viral } & Integrating & Lentiviral (Somers et al., 2010) & $\begin{array}{l}\text { - Ability to infect non-dividing and proliferating } \\
\text { cells i.e., somatic cells }\end{array}$ & $\begin{array}{l}\text { - Incorporation of vector sequence into host } \\
\text { genome } \\
\text { - Solution: single cassette reprogramming } \\
\text { vector } \\
\text { - \& cre/loxp mediated transgene excision e.g., } \\
\text { STEMCCA }\end{array}$ \\
\hline & Non-integrating & $\begin{array}{l}\text { Adenovirus (Zhou and Freed, } \\
\text { 2009) }\end{array}$ & - Does not integrate into host genome & $\begin{array}{l}\text { - Very low reprogramming efficiency compared } \\
\text { to lentiviral delivery }\end{array}$ \\
\hline & & $\begin{array}{l}\text { Sendai virus (RNA virus) (Fusaki } \\
\text { et al., 2009; Ban et al., 2011) }\end{array}$ & $\begin{array}{l}\text { - Does not enter nucleus and gets diluted out } \\
\text { of cells } \\
\text { - Can produce large amounts of protein }\end{array}$ & - Difficult to remove replicating virus \\
\hline \multirow[t]{6}{*}{ Nonviral } & \multicolumn{2}{|c|}{ mRNA transfection (Warren et al., 2010) } & $\begin{array}{l}\text { - No integration into host genome } \\
\text { - Higher efficiency than original retroviral } \\
\text { system } \\
\text { - Commercially available }\end{array}$ & $\begin{array}{l}\text { - Labor intensive } \\
\text { - Technically complex }\end{array}$ \\
\hline & \multicolumn{2}{|c|}{$\begin{array}{l}\text { miRNA transfection (Miyoshi et al., 2011; } \\
\text { Subramanyam et al., 2011) }\end{array}$} & $\begin{array}{l}\text { - Absence of breaks in existing genes } \\
\text { - Avoids reactivation of transgenes }\end{array}$ & $\begin{array}{l}\text { - No established reprogramming protocol } \\
\text { available }\end{array}$ \\
\hline & \multicolumn{2}{|c|}{$\begin{array}{l}\text { Transposons i.e., Piggybac (Kaji et al., 2009; } \\
\text { Woltjen et al., 2009; Yusa et al., 2009) }\end{array}$} & $\begin{array}{l}\text { - Highly active in mammalian cells } \\
\text { - Vector can be removed from the host } \\
\text { genome by expressing transposase }\end{array}$ & - Low reprogramming efficiency \\
\hline & \multicolumn{2}{|c|}{$\begin{array}{l}\text { Episomal plasmids (Yu et al., 2009; Chen et al., } \\
\qquad 2011 \text { ) }\end{array}$} & $\begin{array}{l}\text { - No integration into host genome } \\
\text { - More stable expression compared to } \\
\text { standard plasmids }\end{array}$ & - Requires changes to cell culture methods \\
\hline & \multicolumn{2}{|c|}{$\begin{array}{l}\text { Recombinant proteins (Kim et al., 2009; Zhou et al., } \\
\text { 2009) }\end{array}$} & $\begin{array}{l}\text { - Absence of breaks in existing genes } \\
\text { - Avoids reactivation of transgenes }\end{array}$ & $\begin{array}{l}\text { - Lower reprogramming efficiency compared to } \\
\text { retroviral systems } \\
\text { - Challenging to generate and purify }\end{array}$ \\
\hline & \multicolumn{2}{|c|}{ Small molecules (Hou et al., 2013) } & $\begin{array}{l}\text { - Nonimmunogenic } \\
\text { - Easy to handle }\end{array}$ & $\begin{array}{l}\text { - No established protocol for human somatic } \\
\text { cells }\end{array}$ \\
\hline
\end{tabular}

differentiation within the matrigel droplet, the organoids have to be cultured in a spinning bioreactor to increase diffusion efficiency that promotes tissue survival. Neural organoids can capture the key features of the human brain such as ventriclelike spaces, distinct proliferative layers of cells, and the choroid plexus (Marton and Paşca, 2016); offering a great potential to be used as models of neurodevelopmental and neurodegenerative conditions. Furthermore, protocols have already been established for various brain regions such as cerebral (Lancaster and Knoblich, 2014; Muguruma et al., 2015), forebrain (Qian et al., 2016), and midbrain (Jo et al., 2016) organoids.

Although mostly used to model neurodevelopmental diseases, neural organoids can also be extremely useful for modeling a degenerative disorder such as PD. Since organoids mimick the brain's microenvironment, it has been postulated that culturing of neurons in such a $3 \mathrm{D}$ microenvironment would promote their maturation. Jo et al. (2016) reported the generation of a midbrain organoid with A9 neurons that produces neuromelanin (a dark pigment expressed in the SNpc of humans). So far, none of the $2 \mathrm{D}$ differentiation protocols have given rise in vitro to neuromelanin-producing DA neurons. Of significance, the accumulation of neuromelanin in DA neurons increases with age, suggesting that DA neurons in organoids are far more mature than those in 2D. Comparisons of gene expression between DA neurons cultured in $2 \mathrm{D}$ vs. $3 \mathrm{D}$ organoids also suggest that neurons in organoids are more mature, expressing dopamine transporter (DAT or SLC1A3) (Jo et al., 2016; Monzel et al., 2017), and genetically resembling the prenatal midbrain (Jo et al., 2016). Recently, Monzel et al. (2017) managed to derive midbrain-specific organoids that contained spatially-organized groups of dopaminergic neurons with other neuronal, astroglial, and oligodendrocyte differentiation. Functionally, they detected the presence of synaptic connections and electrophysiological activity. Since PD is an age-onset neurodegenerative disorder, it is critical to model cellular and molecular aspects of the disease with mature and aged neurons rather than neurons of an embryonic resemblance. Moreover, the heterogeneity of cell types within midbrain organoids would be useful to study the interplay and contributions of other cell types to the a-synuclein pathology of PD. As such, midbrain organoids are a very promising platform for investigating late phenotypes associated with $\mathrm{PD}-\mathrm{a}$ unique feature that $2 \mathrm{D}$ culture models cannot offer.

\section{DIRECT REPROGRAMMING OF FIBROBLASTS INTO INDUCED DOPAMINERGIC NEURONS (IDANS)}

Apart from differentiation of iPSCs toward DA neurons that mimic neural developmental processes, overexpression of key transcription factors in patient-derived fibroblasts can be directly transdifferentiated into neurons, including midbrain DA neurons 
(Xu et al., 2017). Wernig and colleagues have reported viralbased transdifferentiation of mouse and human fibroblasts into induced neurons (iNs) by overexpressing up to four neuronal transcription factors, namely, achaetescute homolog 1 (ASCL1), BRN2 (also known as POU3F2), myelin transcription factor 1-like protein (MYT1L) and neuronal differentiation 1 (NEUROD1) (Vierbuchen et al., 2010; Pang et al., 2011). These iNs obtained were morphologically and electrophysiologically similar to bona fide neurons, and resembled excitatory neurons of the cerebral cortex (Heinrich et al., 2014). Building onto this knowledge of direct reprogramming, it has also been shown that midbrain DA neurons can be directly converted from fibroblasts. To do so, several groups have reported direct reprogramming of DA neurons using a cocktail of transcription factors specific to the midbrain lineage (Table 2). The factors that were used for induced DA neurons (iDANs) are extensively reviewed in Jang and Jung (2017). Overall, regardless of the combination of transcription factors used, the efficiency of iDAN conversion from fibroblasts is typically below $20 \%$, even though iDANs demonstrated spontaneous and rebound action potentials which are characteristics of midbrain DA neurons in vivo. This low efficiency of conversion is potentially a limiting factor for disease modeling studies especially when large numbers of cells are required for high throughput screening. Recently, this hurdle has been overcome by a reprogramming strategy that involves ASCL1, LMX1A, and NURR1 in combination with p53-small hairpin RNA (shRNA) and miR-124, as well as small molecule and trophic factor supplements that maintain the identity and survival of midbrain DA neurons (Jiang et al., 2015). This transdifferentiation approach resulted in more than $50 \% \mathrm{TH}^{+}$ iDANs, and it was concluded from this study that G1 arrest was crucial for efficient transdifferentiation, and that addition of patterning small molecules such as SB431542, CHIR99021, Purmorphamine (SHH pathway agonist), Dorsomorphin and trophic factors significantly enhanced reprogramming efficiency.

Another method for generating DA neurons from patient fibroblasts is to derive expandable dopaminergic precursors known as floorplate progenitor cells. This has been achieved in mouse fibroblasts by ectopic expression of Brn2, Sox2, and FoxA2 (Tian et al., 2015), resulting in acquisition of floorplate identity which include expression of Otx2, Corin and Lmx1a expression. Induced floorplate progenitors generated with this method were shown to differentiate primarily into $\mathrm{TH}^{+}$midbrain DA neurons (with more than $90 \%$ efficiency), even without addition of Shh and Fgf8. Although this has not been demonstrated for human cells, we expect similar results based on previous iN studies where

TABLE 2 | List of different strategies used to derive induced dopaminergic neurons. Adapted and revised from Jang and Jung (2017).

\begin{tabular}{|c|c|c|c|c|c|c|c|}
\hline No. & $\begin{array}{l}\text { Type of } \\
\text { transdifferentiated } \\
\text { cells }\end{array}$ & Transcription factors & miRNA & Small molecules & $\begin{array}{c}\mathrm{TH}+ \\
\text { differentiation } \\
\text { efficiency }\end{array}$ & Characterization tests & References \\
\hline 1 & $\begin{array}{l}\text { Human induced } \\
\text { dopaminergic neurons } \\
\text { (iDAN) }\end{array}$ & $\begin{array}{l}\text { Ascl1, Brn2, Myt1l, } \\
\text { Lmx1a and FoxA2 }\end{array}$ & $\mathrm{N} / \mathrm{A}$ & $\mathrm{N} / \mathrm{A}$ & 〜 10\% & $\begin{array}{l}\text { Expression of dopaminergic neuron } \\
\text { markers and electrophysiological profile of } \\
\text { functional dopaminergic neurons }\end{array}$ & $\begin{array}{l}\text { Pfisterer } \\
\text { et al., } 2011\end{array}$ \\
\hline 2 & $\begin{array}{l}\text { Mouse and human } \\
\text { iDAN }\end{array}$ & $\begin{array}{l}\text { Ascl1, Lmx1a } \\
\text { and Nurr1 }\end{array}$ & $\mathrm{N} / \mathrm{A}$ & $\mathrm{N} / \mathrm{A}$ & $\sim 15 \%-20 \%$ & $\begin{array}{l}\text { Expression of dopaminergic neuron } \\
\text { markers, electrophysiological profile of } \\
\text { functional dopaminergic neurons and } \\
\text { dopamine release }\end{array}$ & $\begin{array}{l}\text { Caiazzo et al., } \\
2011\end{array}$ \\
\hline 3 & Mouse iDAN & $\begin{array}{l}\text { Ascl1, Lmx1b } \\
\text { and Nurr1 }\end{array}$ & $\mathrm{N} / \mathrm{A}$ & $\mathrm{N} / \mathrm{A}$ & $\sim 18 \%$ & $\begin{array}{l}\text { Expression of dopaminergic neuron } \\
\text { markers, electrophysiological profile of } \\
\text { functional dopaminergic neurons and } \\
\text { dopamine release }\end{array}$ & $\begin{array}{l}\text { Addis et al., } \\
2011\end{array}$ \\
\hline 4 & Mouse iDAN & $\begin{array}{l}\text { Ascl1, Pitx3, Lmx1a, } \\
\text { Nurr1, FoxA2 and EN1 }\end{array}$ & $\mathrm{N} / \mathrm{A}$ & $\begin{array}{l}\text { Sonic hedgehog } \\
\text { (Shh) and } \\
\text { fibroblast growth } \\
\text { factor } 8 \text { (FGF8) }\end{array}$ & $\sim 7 \%$ & $\begin{array}{l}\text { Expression of dopaminergic neuron } \\
\text { markers, electrophysiological profile of } \\
\text { functional dopaminergic neurons, } \\
\text { dopamine release and relief PD-like } \\
\text { symptoms in PD mice }\end{array}$ & $\begin{array}{l}\text { Kim et al., } \\
2011\end{array}$ \\
\hline 5 & Human iDAN & $\begin{array}{l}\text { Ascl1, Ngn2, Sox2, } \\
\text { Nurr1 and Pitx3 }\end{array}$ & $\mathrm{N} / \mathrm{A}$ & $\mathrm{N} / \mathrm{A}$ & $\sim 40 \%$ & $\begin{array}{l}\text { Expression of dopaminergic neuron } \\
\text { markers, dopamine uptake and release, } \\
\text { electrophysiological profile of functional } \\
\text { dopaminergic neurons and relief PD-like } \\
\text { symptoms in PD mice }\end{array}$ & $\begin{array}{l}\text { Liu et al., } \\
2012\end{array}$ \\
\hline 6 & Human iDAN & $\begin{array}{l}\text { Ascl1, Lmx1a } \\
\text { and Nurr1 }\end{array}$ & miR124 & $\begin{array}{l}\text { p53 suppressor, } \\
\text { G1 cell cycle arrest } \\
\text { and Tet1 agonist }\end{array}$ & $\sim 60 \%$ & $\begin{array}{l}\text { Expression of dopaminergic neuron } \\
\text { markers, DA uptake and release, } \\
\text { electrophysiological profile of functional } \\
\text { dopaminergic neurons }\end{array}$ & $\begin{array}{l}\text { Jiang et al., } \\
2015\end{array}$ \\
\hline 7 & $\begin{array}{l}\text { Mouse induced neural } \\
\text { progenitor cells (iNPCs) } \\
\text { with midbrain identity }\end{array}$ & $\begin{array}{l}\text { Foxa2, Brn2 } \\
\text { and Sox2 }\end{array}$ & $\mathrm{N} / \mathrm{A}$ & $\mathrm{N} / \mathrm{A}$ & $\sim 90 \%$ & $\begin{array}{l}\text { Expression of dopaminergic neuron } \\
\text { proliferative progenitor cell markers, } \\
\text { capable of deriving functional } \\
\text { dopaminergic neurons and to rescue } \\
\text { MPTP-lesioned mice }\end{array}$ & $\begin{array}{l}\text { Tian et al., } \\
2015\end{array}$ \\
\hline
\end{tabular}


the same reprogramming factors worked similarly in mouse and human cells. If so, this could be an ideal method for disease modeling because large numbers of DA neurons can be derived from these self-renewing induced floorplate progenitors.

Although transdifferentiation technologies may not be compatible with neural organoid formation, because directed reprogramming forces fibroblasts to take on a specific cell fate rather than allow for a "self-organizing" approach that is important for organoid formation, there are distinct advantages in using iNs for disease modeling. Two recent studies (Mertens et al., 2015; Huh et al., 2016) found that iNs from aged fibroblasts retained the aging cellular and molecular characteristics while iPSCs made from the same patient fibroblasts were epigenetically reprogrammed to erase the aging signatures and subsequent neurons differentiated from these iPSCs did not acquire aging characteristics. Since PD is an age-onset neurodegenerative disease, iNs that retain aged signatures could be an especially relevant cellular model to understand the role of aging in neuronal decline. It is unclear, however, if induced floorplate progenitors retain aged cellular signatures that also make them suitable models for studying aged-associated neuronal decline.

\section{IPSC-DERIVED MIDBRAIN CULTURES AS AN IN VITRO MODEL OF A-SYN TRANSMISSION}

Despite numerous in vivo and in vitro studies that were discussed in the previous sections demonstrating transmission and propagation of a-syn in PD pathology, there is still a lack of a robust and reproducible in vitro model that could allow us to accurately study its role in PD pathogenesis. As such, it makes it even more difficult to screen for potential therapeutic compounds that could halt PD progression.

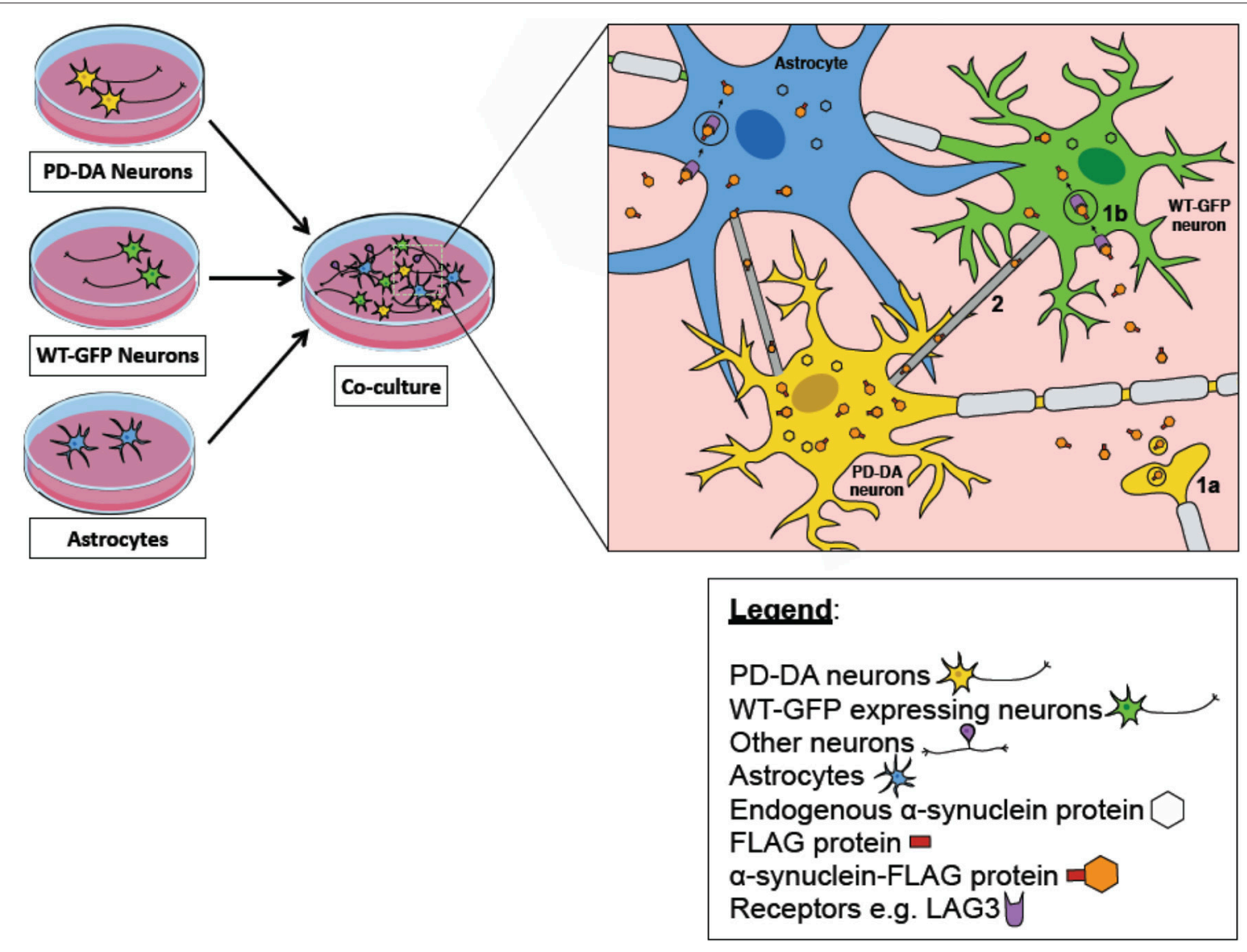

FIGURE 1 | iPSC-derived midbrain cultures as an in vitro model of alpha synuclein transmission. A co-culture model of PD-DA neurons (cells in yellow), WT-GFP neurons (cells in green), and astrocytes (in blue) can be used to track the transfer of pathogenic alpha-synuclein (orange hexagon) between diseased and healthy neurons/astrocytes. PD-DA neurons are derived from the IPSCs of PD patients with their alpha synuclein tagged with a FLAG protein (red rectangle). WT-GFP neurons are derived from the iPSCs of healthy subjects and are constitutively expressing GFP as a reporter-the successful transmission of alpha-synuclein between diseased and healthy neurons can be defined as GFP-expressing cells co-expressing the FLAG signal. Several mechanisms have been postulated to be involved in the propagation of diseased alpha-synuclein to healthy neurons/astrocytes. One mechanism describes that pathogenic alpha synuclein secreted by PD-DA neurons (1a) could interact with various surface proteins on healthy neurons/astrocytes to induce uptake through receptor-mediated endocytosis (1b), for example LAG3 receptor. Furthermore, there are also specialized structures known as tunneling nanotubes (TNTs) between neuron-neuron and neuron-astrocytes that are involved in the spread of alpha synuclein (2). 
One obvious advantage of patient-derived iPSCs is that the iPSCs can be differentiated into disease-relevant DA neurons, and phenotypes observed in these in vitro neurons are well correlated with clinical observations (Torrent et al., 2015). Apart from being an endless source of midbrain DA neurons, using patient-derived cells (with their specific mutations) removes the need to rely on an artificial overexpression system that is not representative of $\mathrm{PD}$ pathology. Recent advances in the CRISPR/Cas9 technology has greatly availed genome-editing strategies to stem cell labs to create isogenic pairs of iPSCs. These typically take the form of "corrected iPSCs" where the disease-causing mutation is corrected to become wild-type, or "mutation-introduced iPSCs," where wild-type iPSCs have their genomic DNA altered into a known disease-causing mutation (Soldner et al., 2011; Hockemeyer and Jaenisch, 2016; Bassett, 2017). The rationale for generating isogenic pairs of iPSCs is to minimize genetic variation that is inherent between different individuals and/or cell lines, and is crucial in disease modeling studies to identify disease-related molecular and cellular events.

Importantly, a-syn aggregation has been observed in DA neurons derived from PD iPSCs. By differentiating a-syn A53T iPSCs into midbrain DA neurons, Kouroupi et al. (2017) detected the presence of the pathological form of asyn that is phosphorylated on serine 129 in the dendrites of PD neurons, reminiscent of Lewy neurites in PD patients (Kouroupi et al., 2017). Protein aggregates, as revealed by Thioflavin S staining, also showed high concentrations of asyn and such inclusion bodies were observed in the cell bodies as well as along neurites. iPSCs derived from patients with PINK1 and Parkin mutations also differentiate into midbrain DA neurons that showed a time-dependent increased a-syn accumulation (Chung et al., 2016). It was also demonstrated that mutant PINK1 and Parkin DA neurons had significantly more insoluble a-syn protein, indicative of aggregated a-syn. These studies have proven that important cellular features of $\mathrm{PD}$ are recapitulated in iPSC-derived neurons, similar to what has been observed for other neurodegenerative diseases.

Critically, what has not been elucidated in these iPSC studies is the transmission and propagation of endogenous a-syn aggregates. While important discoveries pertaining to mechanistic spread of a-syn have been made using exogenouslyadded PFFs, this approach over-simplifies the physiological conditions in which a-syn isoforms exist. Therefore, it remains to be determined if LAG3 or heparan sulfate proteoglycan reduction can protect neurons against a-syn propagation. It would also be important to establish that TNTs transport endogenously-formed a-syn aggregates from host to recipient cells in iNs or iPSC-derived cultures. We propose that these endogenous propagation studies can be performed by coculturing PD iPSC-derived neural cultures with healthy neural cultures, either in 2D or as organoids (Figure 1). One possible method to track a-syn transfer from diseased to healthy cells, a-syn from PD patients has to be tagged with a small reporter protein such as Y-FAST (Plamont et al., 2016), while healthy cells should express a different reporter such as constitutive expression of CFP. Successful transmission events would then be defined as CFP-expressing cells co-stained with Y-FAST. It also remains to be discovered whether monomeric, oligomeric or fibrillar forms of a-syn are transmitted from host to recipient cells.

An advantage of organoid models vs. conventional 2D cultures is that the cytoarchitecture of cells in organoids closely resemble that of a brain-which may enhance neuronal maturation and/or function that promotes aggregate transmission. Since PD is an age-onset neurodegenerative disease, it is also likely that the maturation status of neurons is critical for a-syn transmission. Neurons grown in 3D cultures are also known to be more mature (Jo et al., 2016), and accumulate aggregates (Choi et al., 2014). The heterogeneity of neural cells in organoids is also an ideal system for studying selective neuronal vulnerability in PD. In particular, there are key questions left unanswered: Are specific neural types (astrocytes, DA neurons or other neuronal subtypes) more susceptible to a-syn transmission? What is the molecular signature of neurons with a-syn aggregates? Will attenuating key molecular events downstream of a-syn transmission protect neurons from cell death? Single-cell RNA-seq data of organoid-derived neural cells are expected to give us insights to some of these questions.

\section{CONCLUDING REMARKS}

Alpha synuclein accumulation, aggregation and transmission are key events in the pathology of $\mathrm{PD}$, and strategies to prevent any of these events are thought to be able to slow down disease progression. Patient-derived iPSCs, coupled with the use of genome-editing tools, have become powerful tools in disease modeling, but its utility in modeling a-syn propagation has not been explored. In this review, we present a point-of-view that iNs and iPSC-derived neurons can be a physiologically relevant, all-in-one model that provides the opportunity to study a-syn accumulation, aggregation and transmission concurrently.

\section{AUTHOR CONTRIBUTIONS}

All three authors wrote the manuscript. LYT designed the graphics. S-YN edited the manuscript.

\section{ACKNOWLEDGMENTS}

We thank Winanto for assistance with graphics. YHK is a recipient of the NUS Research Scholarship (YLL School of Medicine/Physiology). This work is funded by the Institute of Molecular and Cell Biology (Biomedical Science Institutes) and the National Medical Research Council (Grant ID: NMRC/OFYIRG/0011/2016). 


\section{REFERENCES}

Abounit, S., Bousset, L., Loria, F., Zhu, S., de Chaumont, F., Pieri, L., et al. (2016). Tunneling nanotubes spread fibrillar alpha-synuclein by intercellular trafficking of lysosomes. EMBO J. 35, 2120-2138. doi: 10.15252/embj.201593411

Addis, R. C., Hsu, F. C., Wright, R. L., Dichter, M. A., Coulter, D. A., and Gearhart, J. D. (2011). Efficient conversion of astrocytes to functional midbrain dopaminergic neurons using a single polycistronic vector. PLoS ONE 6:e28719. doi: 10.1371 /journal.pone.0028719

Alvarez-Erviti, L., Seow, Y., Schapira, A. H., Gardiner, C., Sargent, I. L., Wood, M. J., et al. (2011). Lysosomal dysfunction increases exosomemediated alpha-synuclein release and transmission. Neurobiol Dis. 42, 360-367. doi: 10.1016/j.nbd.2011.01.029

Angot, E., Steiner, J. A., Lema Tomé, C. M., Ekström, P., Mattsson, B., Björklund, A., et al. (2012). Alpha-synuclein cell-to-cell transfer and seeding in grafted dopaminergic neurons in vivo. PLoS ONE 7:e39465. doi: 10.1371/journal.pone.0039465

Ardhanareeswaran, K., Mariani, J., Coppola, G., Abyzov, A., and Vaccarino, F. M. (2017). Human induced pluripotent stem cells for modelling neurodevelopmental disorders. Nat. Rev. Neurol. 13, 265-278. doi: $10.1038 /$ nrneurol.2017.45

Ascherio, A., and Schwarzschild, M. A. (2016). The epidemiology of Parkinson's disease: risk factors and prevention. Lancet Neurol. 15, 1257-1272. doi: 10.1016/S1474-4422(16)30230-7

Ban, H., Nishishita, N., Fusaki, N., Tabata, T., Saeki, K., Shikamura, M., et al. (2011). Efficient generation of transgene-free human induced pluripotent stem cells (iPSCs) by temperature-sensitive Sendai virus vectors. Proc. Natl. Acad. Sci. U S A. 108, 14234-14239. doi: 10.1073/pnas.1103509108

Barker, R. A., Studer, L., Cattaneo, E., Takahashi, J., and G-Force PD consortium (2015). G-Force PD: a global initiative in coordinating stem cell-based dopamine treatments for Parkinson's disease. NPJ Parkinsons Dis. 1:15017. doi: 10.1038/npjparkd.2015.17

Bassett, A. R. (2017). Editing the genome of hiPSC with CRISPR/Cas9: disease models. Mamm. Genome. 28, 348-364. doi: 10.1007/s00335-017-9684-9

Blesa, J., and Przedborski, S. (2014). Parkinson's disease: animal models and dopaminergic cell vulnerability. Front. Neuroanatomy 8:155. doi: 10.3389/fnana.2014.00155

Borghi, R., Marchese, R., Negro, A., Marinelli, L., Forloni, G., Zaccheo, D., et al. (2000). Full length alpha-synuclein is present in cerebrospinal fluid from Parkinson's disease and normal subjects. Neurosci. Lett. 287, 65-67. doi: 10.1016/S0304-3940(00)01153-8

Braak, H., Del Tredici, K., Rüb, U., de Vos, R. A., Jansen Steur, E. N., and Braak, E. (2003). Staging of brain pathology related to sporadic Parkinson's disease. Neurobiol. Aging. 24, 197-211. doi: 10.1016/S0197-4580(02)00065-9

Braak, H., Sastre, M., and Del Tredici, K. (2007). Development of $\alpha$-synuclein immunoreactive astrocytes in the forebrain parallels stages of intraneuronal pathology in sporadic Parkinson's disease. Acta Neuropathologica 114, 231-241. doi: 10.1007/s00401-007-0244-3

Byers, B., Cord, B., Nguyen, H. N., Schüle, B., Fenno, L., Lee, P. C., et al. (2011). SNCA triplication Parkinson's patient's iPSC-derived DA neurons accumulate alpha-synuclein and are susceptible to oxidative stress. PLoS ONE 6:e26159. doi: 10.1371/journal.pone.0026159

Caiazzo, M., Dell'Anno, M. T., Dvoretskova, E., Lazarevic, D., Taverna, S., Leo, D., et al. (2011). Direct generation of functional dopaminergic neurons from mouse and human fibroblasts. Nature 476, 224-227. doi: 10.1038/nature10284

Carey, B. W., Markoulaki, S., Hanna, J., Saha, K., Gao, Q., Mitalipova, M., et al. (2009). Reprogramming of murine and human somatic cells using a single polycistronic vector. Proc. Natl. Acad. Sci. U S A. 106, 157-162. doi: $10.1073 /$ pnas. 0811426106

Chen, G., Gulbranson, D. R., Hou, Z., Bolin, J. M., Ruotti, V., Probasco, M. D., et al. (2011). Chemically defined conditions for human iPSC derivation and culture. Nat. Methods 8, 424-429. doi: 10.1038/nmeth.1593

Choi, S. H., Kim, Y. H., Hebisch, M., Sliwinski, C., Lee, S., D’Avanzo, C., et al. (2014). A three-dimensional human neural cell culture model of Alzheimer's disease. Nature 515, 274-278. doi: 10.1038/nature13800

Chung, S. Y., Kishinevsky, S., Mazzulli, J. R., Graziotto, J., Mrejeru, A., Mosharov, E. V., et al. (2016). Parkin and PINK1 patient iPSC-derived midbrain dopamine neurons exhibit mitochondrial dysfunction and alpha-synuclein accumulation. Stem Cell Rep. 7, 664-677. doi: 10.1016/j.stemcr.2016.08.012

Cooper, O., Hargus, G., Deleidi, M., Blak, A., Osborn, T., Marlow, E., et al. (2010). Differentiation of human ES and Parkinson's disease iPS cells into ventral midbrain dopaminergic neurons requires a high activity form of SHH, FGF8a and specific regionalization by retinoic acid. Mol. Cell. Neurosci. 45, 258-266. doi: 10.1016/j.men.2010.06.017

Cooper, O., Seo, H., Andrabi, S., Guardia-Laguarta, C., Graziotto, J., Sundberg, M., et al. (2012). Pharmacological rescue of mitochondrial deficits in iPSC-derived neural cells from patients with familial Parkinson's disease. Sci. Transl. Med. 4:141 ra90. doi: 10.1126/scitranslmed.3003985

Cuervo, A. M., Stefanis, L., Fredenburg, R., Lansbury, P. T., and Sulzer, D. (2004), Impaired degradation of mutant alpha-synuclein by chaperone-mediated autophagy. Science 305, 1292-1295. doi: 10.1126/science.1101738

Danzer, K. M., Kranich, L. R., Ruf, W. P., Cagsal-Getkin, O., Winslow, A. R., Zhu, L., et al. (2012). Exosomal cell-to-cell transmission of alpha synuclein oligomers. Mol. Neurodegener. 7:42. doi: 10.1186/1750-1326-7-42

Desplats, P., Lee, H. J., Bae, E. J., Patrick, C., Rockenstein, E., Crews, L., et al. (2009). Inclusion formation and neuronal cell death through neuron-to-neuron transmission of alpha-synuclein. Proc. Natl. Acad. Sci. U S A. 106, 13010-13015. doi: 10.1073/pnas.0903691106

Devi, L., Raghavendran, V., Prabhu, B. M., Avadhani, N. G., and Anandatheerthavarada, H. K. (2008). Mitochondrial import and accumulation of alpha-synuclein impair complex I in human dopaminergic neuronal cultures and Parkinson disease brain. J. Biol. Chem. 283, 9089-9100. doi: 10.1074/jbc.M710012200

Devine, M. J., Ryten, M., Vodicka, P., Thomson, A. J., Burdon, T., Houlden, H., et al. (2011). Parkinson's disease induced pluripotent stem cells with triplication of the alpha-synuclein locus. Nat. Commun. 2:440. doi: 10.1038/ncomms1453

Di Giovannantonio, L. G., Di Salvio, M., Acampora, D., Prakash, N., Wurst, W., and Simeone, A. (2013). Otx2 selectively controls the neurogenesis of specific neuronal subtypes of the ventral tegmental area and compensates En1dependent neuronal loss and MPTP vulnerability. Dev. Biol. 373, 176-183. doi: 10.1016/j.ydbio.2012.10.022

Doi, D., Samata, B., Katsukawa, M., Kikuchi, T., Morizane, A., Ono, Y., et al. (2014). Isolation of human induced pluripotent stem cell-derived dopaminergic progenitors by cell sorting for successful transplantation. Stem Cell Rep. 2, 337-350. doi: 10.1016/j.stemcr.2014.01.013

El-Agnaf, O. M., Salem, S. A., Paleologou, K. E., Curran, M. D., Gibson, M. J., Court, J. A., et al. (2006). Detection of oligomeric forms of alpha-synuclein protein in human plasma as a potential biomarker for Parkinson's disease. FASEB J. 20, 419-425. doi: 10.1096/fj.03-1449com

Emmanouilidou, E., Melachroinou, K., Roumeliotis, T., Garbis, S. D., Ntzouni, M., Margaritis, L. H., et al. (2010). Cell-produced alpha-synuclein is secreted in a calcium-dependent manner by exosomes and impacts neuronal survival. $J$. Neurosci. 30, 6838-6851. doi: 10.1523/JNEUROSCI.5699-09.2010

Evans, M. (2011). Discovering pluripotency: 30 years of mouse embryonic stem cells. Nat. Rev. Mol. Cell Biol. 12, 680-686. doi: 10.1038/nrm3190

Fasano, C. A., Chambers, S. M., Lee, G., Tomishima, M. J., and Studer, L. (2010). Efficient derivation of functional floor plate tissue from human embryonic stem cells. Cell Stem Cell 6, 336-347. doi: 10.1016/j.stem.2010.03.001

Fellner, L., Irschick, R., Schanda, K., Reindl, M., Klimaschewski, L., Poewe, W., et al. (2013). Toll-like receptor 4 is required for $\alpha$-synuclein dependent activation of microglia and astroglia. Glia 61, 349-360. doi: 10.1002/glia. 22437

Fernandes, H. J., Hartfield, E. M., Christian, H. C., Emmanoulidou, E., Zheng, Y., Booth, H., et al. (2016). ER stress and autophagic perturbations lead to elevated extracellular alpha-synuclein in GBA-N370S parkinson's iPSC-derived dopamine neurons. Stem Cell Rep. 6, 342-356. doi: $10.1016 /$ j.stemcr.2016.01.013

Flierl, A., Oliveira, L. M., Falomir-Lockhart, L. J., Mak, S. K., Hesley, J., Soldner, F., et al. (2014). Higher vulnerability and stress sensitivity of neuronal precursor cells carrying an alpha-synuclein gene triplication. PLOS ONE 9:e112413. doi: 10.1371/journal.pone.0112413

Fusaki, N., Ban, H., Nishiyama, A., Saeki, K., and Hasegawa, M. (2009). Efficient induction of transgene-free human pluripotent stem cells using a vector based on Sendai virus, an RNA virus that does not integrate into the host genome. Proc. Jpn Acad. Ser. B Phys. Biol. Sci. 85, 348-362. doi: 10.2183/pjab.85.348 
Hansen, C., Angot, E., Bergström, A. L., Steiner, J. A., Pieri, L., Paul, G., et al. (2011). alpha-Synuclein propagates from mouse brain to grafted dopaminergic neurons and seeds aggregation in cultured human cells. J. Clin. Invest. 121, 715-725. doi: 10.1172/JCI43366

Heinrich, C., Bergami, M., Gascón, S., Lepier, A., Viganò, F., Dimou, L., et al. (2014). Sox2-mediated conversion of NG2 glia into induced neurons in the injured adult cerebral cortex. Stem Cell Rep. 3, 1000-1014. doi: 10.1016/j.stemcr.2014.10.007

Hockemeyer, D., and Jaenisch, R. (2016). Induced pluripotent stem cells meet genome editing. Cell Stem Cell 18, 573-586. doi: 10.1016/j.stem.2016.04.013

Holmes, B. B., DeVos, S. L., Kfoury, N., Li, M., Jacks, R., Yanamandra, K., et al. (2013). Heparan sulfate proteoglycans mediate internalization and propagation of specific proteopathic seeds. Proc. Natl. Acad. Sci. U.S.A. 110, E3138-E3147. doi: 10.1073/pnas.1301440110

Hou, P., Li, Y., Zhang, X., Liu, C., Guan, J., Li, H., et al. (2013). Pluripotent stem cells induced from mouse somatic cells by small-molecule compounds. Science 341, 651-654. doi: 10.1126/science.1239278

Huh, C. J., Zhang, B., Victor, M. B., Dahiya, S., Batista, L. F., Horvath, S., et al. (2016). Maintenance of age in human neurons generated by microRNA-based neuronal conversion of fibroblasts. Elife 5:e18648. doi: 10.7554/eLife.18648

Imaizumi, Y., Okada, Y., Akamatsu, W., Koike, M., Kuzumaki, N., Hayakawa, H., et al. (2012). Mitochondrial dysfunction associated with increased oxidative stress and alpha-synuclein accumulation in PARK2 iPSC-derived neurons and postmortem brain tissue. Mol. Brain. 5:35. doi: 10.1186/1756-6606-5-35

Jang, Y., and Jung, J. H. (2017). Direct conversion from skin fibroblasts to functional dopaminergic neurons for biomedical application. Biomed. Dermatol. 1:4. doi: 10.1186/s41702-017-0004-5

Jiang, H., Xu, Z., Zhong, P., Ren, Y., Liang, G., Schilling, H. A., et al. (2015). Cell cycle and $\mathrm{p} 53$ gate the direct conversion of human fibroblasts to dopaminergic neurons. Nat. Commun. 6:10100. doi: 10.1038/ncomms10100

Jo, J., Xiao, Y., Sun, A. X., Cukuroglu, E., Tran, H. D., Göke, J., et al. (2016). Midbrain-like organoids from human pluripotent stem cells contain functional dopaminergic and neuromelanin-producing neurons. Cell Stem Cell 19, 248-257. doi: 10.1016/j.stem.2016.07.005

Kaji, K., Norrby, K., Paca, A., Mileikovsky, M., Mohseni, P., and Woltjen, K. (2009). Virus-free induction of pluripotency and subsequent excision of reprogramming factors. Nature 458, 771-775. doi: 10.1038/nature07864

Kamp, F., Exner, N., Lutz, A. K., Wender, N., Hegermann, J., Brunner, B., et al. (2010). Inhibition of mitochondrial fusion by alpha-synuclein is rescued by PINK1, Parkin and DJ-1. EMBO J. 29, 3571-3589. doi: 10.1038/emboj.2010.223

Kanaan, N. M., and Manfredsson, F. P. (2012). Loss of functional alphasynuclein: a toxic event in Parkinson's disease? J. Parkinsons. Dis. 2, 249-267. doi: 10.3233/JPD-012138

Karpinar, D. P., Balija, M. B., Kugler, S., Opazo, F., Rezaei-Ghaleh, N., Wender, N., et al. (2009). Pre-fibrillar alpha-synuclein variants with impaired beta-structure increase neurotoxicity in Parkinson's disease models. EMBO J. 28, 3256-3268. doi: 10.1038/emboj.2009.257

Kawasaki, H., Mizuseki, K., Nishikawa, S., Kaneko, S., Kuwana, Y., Nakanishi, S., et al. (2000). Induction of midbrain dopaminergic neurons from ES cells by stromal cell-derived inducing activity. Neuron 28, 31-40. doi: 10.1016/S0896-6273(00)00083-0

Kim, D., Kim, C. H., Moon, J. I., Chung, Y. G., Chang, M. Y., Han, B. S., et al. (2009). Generation of human induced pluripotent stem cells by direct delivery of reprogramming proteins. Cell Stem Cell 4, 472-476. doi: 10.1016/j.stem.2009.05.005

Kim, J., Su, S. C., Wang, H., Cheng, A. W., Cassady, J. P., Lodato, M. A., et al. (2011). Functional integration of dopaminergic neurons directly converted from mouse fibroblasts. Cell Stem Cell 9, 413-419. doi: 10.1016/j.stem.2011.09.011

Kirkeby, A., Grealish, S., Wolf, D. A., Nelander, J., Wood, J., Lundblad, M., et al. (2012). Generation of regionally specified neural progenitors and functional neurons from human embryonic stem cells under defined conditions. Cell Rep. 1, 703-714. doi: 10.1016/j.celrep.2012.04.009

Kirkeby, A., and Parmar, M. (2012). Building authentic midbrain dopaminergic neurons from stem cells - lessons from development. Transl. Neurosci. 3, 314-319. doi: 10.2478/s13380-012-0041-x

Kisos, H., Pukaß, K., Ben-Hur, T., Richter-Landsberg, C., and Sharon, R. (2012). Increased neuronal $\alpha$-synuclein pathology associates with its accumulation in oligodendrocytes in mice modeling $\alpha$-synucleinopathies. PLoS ONE 7:e46817. doi: 10.1371 /journal.pone.0046817

Klein, C., and Westenberger, A. (2012). Genetics of Parkinson's disease. Cold Spring Harb. Perspect. Med. 2:a008888. doi: 10.1101/cshperspect.a008888

Konno, M., Hasegawa, T., Baba, T., Miura, E., Sugeno, N., Kikuchi, A., et al. (2012). Suppression of dynamin GTPase decreases $\alpha$-synuclein uptake by neuronal and oligodendroglial cells: a potent therapeutic target for synucleinopathy. Mol. Neurodegener. 7:38. doi: 10.1186/1750-1326-7-38

Kordower, J. H., Chu, Y., Hauser, R. A., Freeman, T. B., and Olanow, C. W. (2008). Lewy body-like pathology in long-term embryonic nigral transplants in Parkinson's disease. Nat. Med. 14, 504-506. doi: 10.1038/nm1747

Kordower, J. H., Dodiya, H. B., Kordower, A. M., Terpstra, B., Paumier, K., Madhavan, L., et al. (2011). Transfer of host-derived alpha synuclein to grafted dopaminergic neurons in rat. Neurobiol. Dis. 43, 552-557. doi: 10.1016/j.nbd.2011.05.001

Kouroupi, G., Taoufik, E., Vlachos, I. S., Tsioras, K., Antoniou, N., Papastefanaki, F., et al. (2017). Defective synaptic connectivity and axonal neuropathology in a human iPSC-based model of familial Parkinson's disease. Proc. Natl. Acad. Sci. USA. 114, E3679-E88. doi: 10.1073/pnas.1617259114

Kriks, S., Shim, J. W., Piao, J., Ganat, Y. M., Wakeman, D. R., Xie, Z., et al. (2011). Dopamine neurons derived from human ES cells efficiently engraft in animal models of Parkinson's disease. Nature 480, 547-551. doi: 10.1038/nature10648

Lancaster, M. A., and Knoblich, J. A. (2014). Generation of cerebral organoids from human pluripotent stem cells. Nat. Protoc. 9, 2329-2340. doi: 10.1038/nprot.2014.158

Lancaster, M. A., Renner, M., Martin, C. A., Wenzel, D., Bicknell, L. S., Hurles, M. E., et al. (2013). Cerebral organoids model human brain development and microcephaly. Nature 501, 373-379. doi: 10.1038/nature12517

Lashuel, H. A., Overk, C. R., Oueslati, A., and Masliah, E. (2012). The many faces of $\alpha$-synuclein: from structure and toxicity to therapeutic target. Nat. Rev. Neurosci. 14:38-48. doi: 10.1038/nrn3406

Lee, H. J., Cho, E. D., Lee, K. W., Kim, J. H., Cho, S. G., and Lee, S. J. (2013). Autophagic failure promotes the exocytosis and intercellular transfer of alphasynuclein. Exp. Mol. Med. 45:e22. doi: 10.1038/emm.2013.45

Lee, H. J., Suk, J. E., Patrick, C., Bae, E. J., Cho, J. H., Rho, S., et al. (2010). Direct transfer of alpha-synuclein from neuron to astroglia causes inflammatory responses in synucleinopathies. J. Biol. Chem. 285, 9262-9272. doi: 10.1074/jbc.M109.081125

Lee, P. H., Lee, G., Park, H. J., Bang, O. Y., Joo, I. S., and Huh, K. (2006). The plasma alpha-synuclein levels in patients with Parkinson's disease and multiple system atrophy. J. Neural. Transm. 113, 1435-1439. doi: 10.1007/s00702-005-0427-9

Li, J. Y., Englund, E., Holton, J. L., Soulet, D., Hagell, P., Lees, A. J., et al. (2008). Lewy bodies in grafted neurons in subjects with Parkinson's disease suggest host-to-graft disease propagation. Nat. Med. 14, 501-503. doi: 10.1038/nm1746

Lindström, V., Gustafsson, G., Sanders, L. H., Howlett, E. H., Sigvardson, J., Kasrayan, A., et al. (2017). Extensive uptake of $\alpha$-synuclein oligomers in astrocytes results in sustained intracellular deposits and mitochondrial damage. Mol. Cell. Neurosci. 82, 143-156. doi: 10.1016/j.mcn.2017.04.009

Liu, X., Li, F., Stubblefield, E. A., Blanchard, B., Richards, T. L., Larson, G. A., et al. (2012). Direct reprogramming of human fibroblasts into dopaminergic neuron-like cells. Cell Res. 22, 321-332. doi: 10.1038/cr.2011.181

Luk, K. C., Kehm, V., Carroll, J., Zhang, B., O’Brien, P., Trojanowski, J. Q., et al. (2012a). Pathological alpha-synuclein transmission initiates Parkinsonlike neurodegeneration in nontransgenic mice. Science 338, 949-953. doi: 10.1126/science.1227157

Luk, K. C., Kehm, V. M., Zhang, B., O’Brien, P., Trojanowski, J. Q., and Lee, V. M. (2012b). Intracerebral inoculation of pathological alpha-synuclein initiates a rapidly progressive neurodegenerative alpha-synucleinopathy in mice. J. Exp. Med. 209, 975-986. doi: 10.1084/jem.20112457

Malik, N., and Rao, M. S. (2013). A review of the methods for human iPSC derivation. Methods Mol. Biol. 997:23-33. doi: 10.1007/978-1-62703-348-0_3

Mao, X., Ou, M. T., Karuppagounder, S. S., Kam, T. I., Yin, X., Xiong, Y., et al. (2016). Pathological alpha-synuclein transmission initiated by binding lymphocyte-activation gene 3. Science 353:aah3374. doi: $10.1126 /$ science.aah3374

Marton, R. M., and Paşca, S. P. (2016). Neural differentiation in the third dimension: generating a human midbrain. Cell Stem Cell 19, 145-146. doi: 10.1016/j.stem.2016.07.017 
Masuda-Suzukake, M., Nonaka, T., Hosokawa, M., Kubo, M., Shimozawa, A., Akiyama, H., et al. (2014). Pathological alpha-synuclein propagates through neural networks. Acta Neuropathologica Commun. 2:88. doi: 10.1186/s40478-014-0088-8

Mertens, J., Paquola, A. C., Ku, M., Hatch, E., Böhnke, L., Ladjevardi, S., et al. (2015). Directly reprogrammed human neurons retain aging-associated transcriptomic signatures and reveal age-related nucleocytoplasmic defects. Cell Stem Cell 17, 705-718. doi: 10.1016/j.stem.2015.09.001

Miller, D., Johnson, J., Solano, S., Hollingsworth, Z., Standaert, D., and Young, A. (2005). Absence of $\alpha$-synuclein mRNA expression in normal and multiple system atrophy oligodendroglia. J. Neural Transm. 112, 1613-1624. doi: 10.1007/s00702-005-0378-1

Miyoshi, N., Ishii, H., Nagano, H., Haraguchi, N., Dewi D., L., Kano, Y., et al. (2011). Reprogramming of mouse and human cells to pluripotency using mature microRNAs. Cell Stem Cell 8, 633-638. doi: 10.1016/j.stem.2011.05.001

Monzel, A. S., Smits, L. M., Hemmer, K., Hachi, S., Moreno, E. L., van Wuellen, T., et al. (2017). Derivation of human midbrain-specific organoids from neuroepithelial stem cells. Stem Cell Rep. 8, 1144-1154. doi: 10.1016/j.stemcr.2017.03.010

Mougenot, A. L., Nicot, S., Bencsik, A., Morignat, E., Verchère, J., Lakhdar, L., et al. (2012). Prion-like acceleration of a synucleinopathy in a transgenic mouse model. Neurobiol. Aging 33, 2225-2228. doi: 10.1016/j.neurobiolaging.2011.06.022

Muguruma, K., Nishiyama, A., Kawakami, H., Hashimoto, K., and Sasai, Y. (2015). Self-organization of polarized cerebellar tissue in 3D culture of human pluripotent stem cells. Cell Rep. 10, 537-550. doi: 10.1016/j.celrep.2014.12.051

Nakamura, K., Nemani, V. M., Azarbal, F., Skibinski, G., Levy, J. M., Egami, K., et al. (2011). Direct membrane association drives mitochondrial fission by the Parkinson disease-associated protein alpha-synuclein. J. Biol. Chem. 286, 20710-20726. doi: 10.1074/jbc.M110.213538

Paik, E. J., O’Neil, A. L., Ng, S. Y., Sun, C., and Rubin, L. L. (2018). Using intracellular markers to identify a novel set of surface markers for live cell purification from a heterogeneous hIPSC culture. Sci. Rep. 8, 804. doi: 10.1038/s41598-018-19291-4

Pang, Z. P., Yang, N., Vierbuchen, T., Ostermeier, A., Fuentes, D. R., Yang, T. Q., et al. (2011). Induction of human neuronal cells by defined transcription factors. Nature 476:220-223. doi: 10.1038/nature10202

Panman, L., Papathanou, M., Laguna, A., Oosterveen, T., Volakakis, N., Acampora, D., et al. (2014). Sox6 and Otx2 control the specification of substantia nigra and ventral tegmental area dopamine neurons. Cell Rep. 8, 1018-1025. doi: 10.1016/j.celrep.2014.07.016

Pan-Montojo, F., Anichtchik, O., Dening, Y., Knels, L., Pursche, S., Jung, R., et al. (2010). Progression of Parkinson's disease pathology is reproduced by intragastric administration of rotenone in mice. PLOS ONE 5:e8762. doi: 10.1371/journal.pone.0008762

Pan-Montojo, F., Schwarz, M., Winkler, C., Arnhold, M., O’Sullivan, G. A., Pal, A., et al. (2012). Environmental toxins trigger PD-like progression via increased alpha-synuclein release from enteric neurons in mice. Sci. Rep. 2:898. doi: 10.1038/srep00898

Peelaerts, W., Bousset, L., Van der Perren, A., Moskalyuk, A., Pulizzi, R., Giugliano, M., et al. (2015). alpha-Synuclein strains cause distinct synucleinopathies after local and systemic administration. Nature 522, 340-344. doi: 10.1038/nature14547

Perrier, A. L., Tabar, V., Barberi, T., Rubio, M. E., Bruses, J., Topf, N., et al. (2004). Derivation of midbrain dopamine neurons from human embryonic stem cells. Proc. Natl. Acad. Sci. U.S.A. 101, 12543-12548. doi: 10.1073/pnas.0404700101

Pfisterer, U., Kirkeby, A., Torper, O., Wood, J., Nelander, J., Dufour, A., et al. (2011). Direct conversion of human fibroblasts to dopaminergic neurons. Proc. Natl. Acad. Sci. USA. 108, 10343-10348. doi: 10.1073/pnas.1105135108

Plamont, M. A., Billon-Denis, E., Maurin, S., Gauron, C., Pimenta, F. M., Specht, C. G., et al. (2016). Small fluorescence-activating and absorption-shifting tag for tunable protein imaging in vivo. Proc. Natl. Acad. Sci. USA. 113, 497-502. doi: $10.1073 /$ pnas. 1513094113

Poulin, J. F., Zou, J., Drouin-Ouellet, J., Kim K-Y, A., Cicchetti, F., and Awatramani, R. B. (2014). Defining midbrain dopaminergic neuron diversity by single-cell gene expression profiling. Cell Rep. 9, 930-943. doi: 10.1016/j.celrep.2014.10.008
Qian, X., Nguyen, H. N., Song, M. M., Hadiono, C., Ogden, S. C., Hammack, C., et al. (2016). Brain region-specific organoids using mini-bioreactors for modeling ZIKV exposure. Cell 165, 1238-1254. doi: 10.1016/j.cell.2016.04.032

Rannikko, E. H., Weber, S. S., and Kahle, P. J. (2015). Exogenous $\alpha$-synuclein induces toll-like receptor 4 dependent inflammatory responses in astrocytes. BMC Neurosci. 16:57. doi: 10.1186/s12868-015-0192-0

Recasens, A., Dehay, B., Bové, J., Carballo-Carbajal, I., Dovero, S., Pérez-Villalba, A., et al. (2014). Lewy body extracts from Parkinson disease brains trigger alpha-synuclein pathology and neurodegeneration in mice and monkeys. Ann. Neurol. 75, 351-362. doi: 10.1002/ana.24066

Rey, N. L., Petit, G. H., Bousset, L., Melki, R., and Brundin, P. (2013). Transfer of human alpha-synuclein from the olfactory bulb to interconnected brain regions in mice. Acta Neuropathol. 126, 555-573. doi: 10.1007/s00401-013-1160-3

Reyes, J. F., Rey, N. L., Bousset, L., Melki, R., Brundin, P., and Angot, E. (2014). Alpha-synuclein transfers from neurons to oligodendrocytes. Glia 62, 387-398. doi: 10.1002/glia.22611

Rostami, J., Holmqvist, S., Lindström, V., Sigvardson, J., Westermark, G. T., Ingelsson, M., et al. (2017). Human astrocytes transfer aggregated alpha-synuclein via tunneling nanotubes. J. Neurosci. 37, 11835-11853. doi: 10.1523/JNEUROSCI.0983-17.2017

Ryan, S. D., Dolatabadi, N., Chan, S. F., Zhang, X., Akhtar, M. W., Parker, J., et al. (2013). Isogenic human iPSC Parkinson's model shows nitrosative stressinduced dysfunction in MEF2-PGC1alpha transcription. Cell 155, 1351-1364. doi: 10.1016/j.cell.2013.11.009

Sacino, A. N., Brooks, M., McGarvey, N. H., McKinney, A. B., Thomas, M. A., Levites, Y., et al. (2013). Induction of CNS alpha-synuclein pathology by fibrillar and non-amyloidogenic recombinant alpha-synuclein. Acta Neuropathol. Commun. 1:38. doi: 10.1186/2051-5960-1-38

Seki, T., and Fukuda, K. (2015). Methods of induced pluripotent stem cells for clinical application. World J. Stem Cells 7, 116-125. doi: 10.4252/wjsc.v7.i1.116

Shaltouki, A., Sivapatham, R., Pei, Y., Gerencser, A. A., Momcilović, O., Rao, M. S., et al. (2015). Mitochondrial alterations by PARKIN in dopaminergic neurons using PARK2 patient-specific and PARK2 knockout isogenic iPSC lines. Stem Cell Rep. 4, 847-859. doi: 10.1016/j.stemcr.2015.02.019

Sharon, R., Goldberg, M. S., Bar-Josef, I., Betensky, R. A., Shen, J., and Selkoe, D. J. (2001). alpha-Synuclein occurs in lipid-rich high molecular weight complexes, binds fatty acids, and shows homology to the fatty acid-binding proteins. Proc. Natl. Acad. Sci. USA. 98, 9110-9115. doi: 10.1073/pnas.171300598

Shimozawa, A., Ono, M., Takahara, D., Tarutani, A., Imura, S., Masuda-Suzukake, M., et al. (2017). Propagation of pathological alpha-synuclein in marmoset brain. Acta Neuropathol. Commun. 5:12. doi: 10.1186/s40478-017-0413-0

Snyder, H., Mensah, K., Theisler, C., Lee, J., Matouschek, A., and Wolozin, B. (2003). Aggregated and monomeric alpha-synuclein bind to the S6' proteasomal protein and inhibit proteasomal function. J. Biol. Chem. 278, 11753-11759. doi: 10.1074/jbc.M208641200

Soldner, F., Laganière, J., Cheng, A. W., Hockemeyer, D., Gao, Q., Alagappan, R., et al. (2011). Generation of isogenic pluripotent stem cells differing exclusively at two early onset Parkinson point mutations. Cell 146, 318-331. doi: 10.1016/j.cell.2011.06.019

Somers, A., Jean, J. C., Sommer, C. A., Omari, A., Ford, C. C., Mills, J. A., et al. (2010). Generation of transgene-free lung disease-specific human iPS cells using a single excisable lentiviral stem cell cassette. Stem Cells 28, 1728-1740. doi: 10.1002/stem.495

Sommer, C. A., Stadtfeld, M., Murphy, G. J., Hochedlinger, K., Kotton, D. N., and Mostoslavsky, G. (2009). iPS cell generation using a single lentiviral stem cell cassette. Stem Cells 27, 543-549. doi: 10.1634/stemcells.2008-1075

Stefanis, L. (2012). alpha-synuclein in Parkinson's disease. Cold Spring Harb. Perspect. Med. 2:a009399. doi: 10.1101/cshperspect.a009399

Stefanis, L., Larsen, K. E., Rideout, H. J., Sulzer, D., and Greene, L. A. (2001). Expression of A53T mutant but not wild-type alpha-synuclein in PC12 cells induces alterations of the ubiquitin-dependent degradation system, loss of dopamine release, and autophagic cell death. J. Neurosci. 21, 9549-9560. doi: 10.1523/JNEUROSCI.21-24-09549.2001

Stefanova, N., Fellner, L., Reindl, M., Masliah, E., Poewe, W., and Wenning, G. K. (2011). Toll-like receptor 4 promotes $\alpha$-synuclein clearance and survival of nigral dopaminergic neurons. Am. J. Pathol. 179, 954-963. doi: 10.1016/j.ajpath.2011.04.013 
Stuendl, A., Kunadt, M., Kruse, N., Bartels, C., Moebius, W., Danzer, K. M., et al. (2016). Induction of alpha-synuclein aggregate formation by CSF exosomes from patients with Parkinson's disease and dementia with Lewy bodies. Brain 139(Pt 2), 481-494. doi: 10.1093/brain/awv346

Subramanyam, D., Lamouille, S., Judson, R. L., Liu, J. Y., Bucay, N., Derynck, R., et al. (2011). Multiple targets of miR-302 and miR-372 promote reprogramming of human fibroblasts to induced pluripotent stem cells. Nat. Biotechnol. 29, 443-448. doi: 10.1038/nbt.1862

Takahashi, K., and Yamanaka, S. (2006). Induction of pluripotent stem cells from mouse embryonic and adult fibroblast cultures by defined factors. Cell 126, 663-676. doi: 10.1016/j.cell.2006.07.024

Tanaka, Y., Engelender, S., Igarashi, S., Rao, R. K., Wanner, T., Tanzi, R. E., et al. (2001). Inducible expression of mutant alpha-synuclein decreases proteasome activity and increases sensitivity to mitochondria-dependent apoptosis. Hum. Mol. Genet. 10, 919-926. doi: 10.1093/hmg/10.9.919

Thakur, P., Breger, L. S., Lundblad, M., Wan, O. W., Mattsson, B., Luk, K. C., et al. (2017). Modeling Parkinson's disease pathology by combination of fibril seeds and alpha-synuclein overexpression in the rat brain. Proc. Natl. Acad. Sci. USA. 114, E8284-E93. doi: 10.1073/pnas.1710442114

Tian, C., Li, Y., Huang, Y., Wang, Y., Chen, D., Liu, J., et al. (2015). Selective generation of dopaminergic precursors from mouse fibroblasts by direct lineage conversion. Sci. Rep. 5:12622. doi: 10.1038/srep12622

Tokuda, T., Salem, S. A., Allsop, D., Mizuno, T., Nakagawa, M., Qureshi, M. M., et al. (2006). Decreased alpha-synuclein in cerebrospinal fluid of aged individuals and subjects with Parkinson's disease. Biochem. Biophys. Res. Commun. 349, 162-166. doi: 10.1016/j.bbrc.2006.08.024

Torrent, R., De Angelis Rigotti, F., Dell'Era, P., Memo, M., Raya, A., and Consiglio, A. (2015). Using iPS cells toward the understanding of Parkinson's disease. J. Clin. Med. 4, 548-566. doi: 10.3390/jcm4040548

Ubhi, K., Low, P., and Masliah, E. (2011). Multiple system atrophy: a clinical and neuropathological perspective. Trends Neurosci. 34, 581-590. doi: 10.1016/j.tins.2011.08.003

Vierbuchen, T., Ostermeier, A., Pang, Z. P., Kokubu, Y., Südhof, T. C., and Wernig, M. (2010). Direct conversion of fibroblasts to functional neurons by defined factors. Nature 463, 1035-1041. doi: 10.1038/nature 08797

Warren, L., Manos, P. D., Ahfeldt, T., Loh, Y.-H., Li, H., Lau, F., et al. (2010). Highly efficient reprogramming to pluripotency and directed differentiation of human cells using synthetic modified mRNA. Cell Stem Cell 7, 618-630. doi: 10.1016/j.stem.2010.08.012

Winner, B., Jappelli, R., Maji, S. K., Desplats, P. A., Boyer, L., Aigner, S., et al. (2011). In vivo demonstration that alpha-synuclein oligomers are toxic. Proc. Natl. Acad. Sci. U.S.A. 108, 4194-4199. doi: 10.1073/pnas.1100 976108
Woltjen, K., Michael, I. P., Mohseni, P., Desai, R., Mileikovsky, M., Hämäläinen, R., et al. (2009). piggyBac transposition reprograms fibroblasts to induced pluripotent stem cells. Nature 458, 766-770. doi: 10.1038/nature07863

Xilouri, M., Vogiatzi, T., Vekrellis, K., Park, D., and Stefanis, L. (2009). Abberant alpha-synuclein confers toxicity to neurons in part through inhibition of chaperone-mediated autophagy. PLoS ONE 4:e5515. doi: 10.1371/journal.pone.0005515

Xu, Z., Chu, X., Jiang, H., Schilling, H., Chen, S., and Feng, J. (2017). Induced dopaminergic neurons: a new promise for Parkinson's disease. Redox Biol. 11:606-612. doi: 10.1016/j.redox.2017.01.009

Yu, J., Hu, K., Smuga-Otto, K., Tian, S., Stewart, R., Slukvin, I. I., et al. (2009). Human induced pluripotent stem cells free of vector and transgene sequences. Science 324, 797-801. doi: 10.1126/science.1172482

Yu, W.-W., Cao, S.-N., Zang, C.-X., Wang, L., Yang, H.-Y., Bao, X.-Q., et al. (2018). Heat shock protein 70 suppresses neuroinflammation induced by $\alpha$-synuclein in astrocytes. Mol. Cell. Neurosci. 86:58-64. doi: 10.1016/j.mcn.2017.11.013

Yusa, K., Rad, R., Takeda, J., and Bradley, A. (2009). Generation of transgenefree induced pluripotent mouse stem cells by the piggyBac transposon. Nat. Methods 6, 363-369. doi: 10.1038/nmeth.1323

Zhang, S. C., Wernig, M., Duncan, I. D., Brüstle, O., and Thomson, J. A. (2001). In vitro differentiation of transplantable neural precursors from human embryonic stem cells. Nat. Biotechnol. 19, 1129-1133. doi: $10.1038 /$ nbt1201-1129

Zhang, W., Wang, T., Pei, Z., Miller, D. S., Wu, X., Block, M. L., et al. (2005). Aggregated $\alpha$-synuclein activates microglia: a process leading to disease progression in Parkinson's disease. FASEB J. 19, 533-542. doi: 10.1096/fj.04-2751com

Zhou, H., Wu, S., Joo, J. Y., Zhu, S., Han, D. W., Lin, T., et al. (2009). Generation of induced pluripotent stem cells using recombinant proteins. Cell Stem Cell 4 , 381-384. doi: 10.1016/j.stem.2009.04.005

Zhou, W., and Freed, C. R. (2009). Adenoviral gene delivery can reprogram human fibroblasts to induced pluripotent stem cells. Stem Cells 27, 2667-2674 doi: $10.1002 /$ stem.201

Conflict of Interest Statement: The authors declare that the research was conducted in the absence of any commercial or financial relationships that could be construed as a potential conflict of interest.

Copyright (c) $2018 \mathrm{Koh}$, Tan and Ng. This is an open-access article distributed under the terms of the Creative Commons Attribution License (CC BY). The use, distribution or reproduction in other forums is permitted, provided the original author(s) and the copyright owner(s) are credited and that the original publication in this journal is cited, in accordance with accepted academic practice. No use, distribution or reproduction is permitted which does not comply with these terms. 